\title{
Buddhism and the State: The New Relationship
}

Increasing numbers of believers bring great changes to the monastic economy in China

Zhe Ji

\section{OpenEdition}

\section{Journals}

Édition électronique

URL : http://journals.openedition.org/chinaperspectives/408

DOI : $10.4000 /$ chinaperspectives.408

ISSN : 1996-4617

Éditeur

Centre d'étude français sur la Chine contemporaine

\section{Édition imprimée}

Date de publication : 1 octobre 2004

ISSN : 2070-3449

Référence électronique

Zhe Ji, «Buddhism and the State: The New Relationship », China Perspectives [En ligne], 55 I september - october 2004, mis en ligne le 24 juin 2008, consulté le 10 décembre 2020. URL : http://

journals.openedition.org/chinaperspectives/408; DOI : https://doi.org/10.4000/chinaperspectives. 408

Ce document a été généré automatiquement le 10 décembre 2020.

(C) All rights reserved 


\section{Buddhism and the State: The New Relationship}

Increasing numbers of believers bring great changes to the monastic economy in China

Zhe Ji

\section{NOTE DE L'ÉDITEUR}

Translated from the French original by Philip Liddell

1 Buddhism, like other religions or traditional forms of worship, has boomed in China over the past twenty years. This renaissance may be explained first of all by a softening of the state's policy towards religion since the reforms were launched at the end of the 1970s. China's Buddhists now enjoy greater freedom to restore the monasteries, recruit novices, organise ceremonies and spread their beliefs. The progressive discrediting of the utopian grand narrative of communist society that once underlay the value system defined by the state is also leading more and more individuals to turn-or turn backtowards Buddhism. Buddhism helps them to find meaning in their experience of living in a changing society. 
In 2002 Shaolin Temple in Henan celebrated the $1500^{\text {th }}$ anniversary of its founding

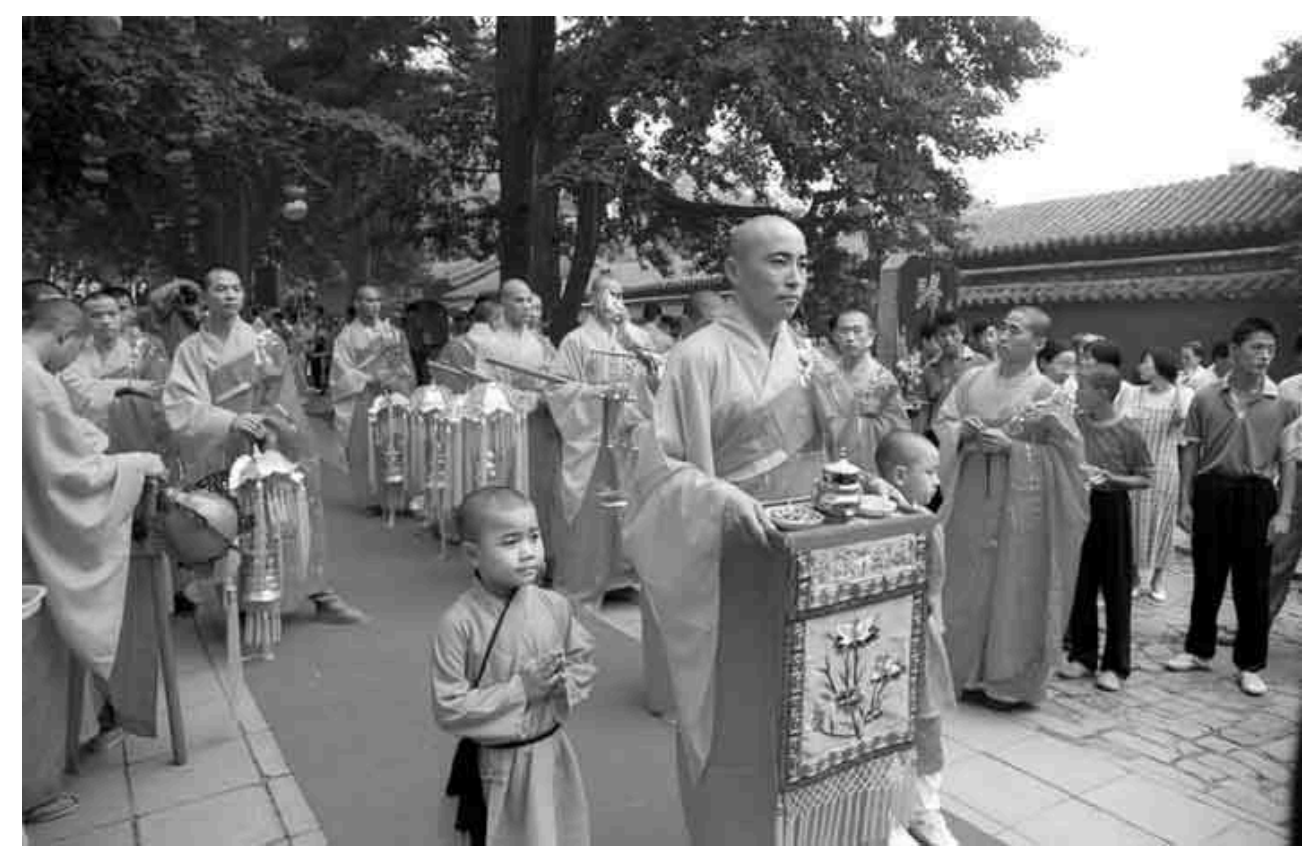

(C) Imaginechina

2 But to see the new growth of Buddhism in China as merely the result of political liberalisation and the discrediting of official ideology would be to reduce the relationship between the state and religion-in this case, Buddhism-to a sort of zerosum game, in which the strengthening of one force must lead to the weakening of the other, and vice versa. This approach to the relationship between the state and religion is simplistic and does not reflect the Chinese reality, neither in the past nor in the present. The Chinese state and Buddhism have an extremely complex and everchanging relationship ${ }^{1}$. While oppression and strict controls do still exist, negotiations and compromises are present too. Sometimes the state even contributes to rehabilitating and promoting Buddhism. In recent years, the Chinese government has worked enthusiastically to build, rebuild or renovate Buddhist monuments. We may cite two examples among so many. In Sanya, on Hainan Island, where Buddhism formerly had little influence, the building of the Nanshan Temple, a great temple in the Tang style, was undertaken in 1995 with the support of the provincial government. Occupying an area of 26.7 hectares, it was opened to the public in 1998. In the city of Wuxi, in Jiangsu province, a huge 88-metre statue of the Buddha was erected in 1997, and significant work is in progress on laying out the surrounding gardens dedicated to Buddhist culture. The province sets great store by this project.

3 How should we understand this relationship between the state and Buddhism, made up as it is of tensions and ambiguities? It is possible to understand it from various points of view $^{2}$. This article approaches this question from the angle of the monastic economy and its development. Based on a historical review of the main characteristics of the monastic economy and on my own field studies, it analyses the development of the state's relationship with Buddhism in the context of the diversification of economic and social exchanges in China over the past twenty years.

"Combining Chan with agricultural work": an economic strategy in conformity with political ideology 

Cultural Revolution (1966-1976), the Buddhist Association of China adopted as one of its main slogans the expression "combining Chan ${ }^{3}$ with agricultural work" (nong chan bingzhong/ju). The aim was to encourage the monks to take up productive labour alongside their religious activities, in particular agricultural work, to establish a monastic economy that might be self-sufficient.

5 This approach was not entirely new. Indeed, the slogan has its origin in the work of Taixu (1889-1947), the most famous Chinese Buddhist reformer of the twentieth century ${ }^{4}$. At the end of the 1920s, Taixu was inspired by the monastic regulation introduced by the Chan master Baizhang Huaihai (749-814) of the Tang Dynasty, which stressed the need to live on the fruit of one's own labour in the fields ${ }^{5}$; accordingly, Taixu suggested that Buddhists should take up this "agricultural Chan" (nong chan) and to develop it into "work Chan" (gong Chan). Taixu hoped thus to encourage the monks, particularly those less suited to Buddhist studies, to take up profitable work, whether agricultural, commercial or industrial ${ }^{6}$. However, his conception was never really tried out.

6 In 1950, shortly after the Chinese People's Republic was proclaimed, one of Taixu's disciples, Juzan (1908-1984), a monk who was close to the Communist Party, took up his master's idea. This time, the combination of Chan and "work" became one of the principal means of adapting Buddhism to the communist revolution. Before 1949, the monks lived mainly on the farm rents that they received, donations from the faithful and income from religious services ${ }^{7}$. So the new government saw monks as exploiters and as parasitic dependants on the feudal regime. In this situation, Juzan, supported by a minority within the Buddhist elite eager to conform to the revolution's demands, proposed to "completely reform the present Buddhist system by productive labour", in order to "eliminate the status of landlords (dizhu) of the monasteries, the system of private ownership of the hereditary monasteries and the superstitious services" 8 . That is how the expression "combining Chan ${ }^{9}$ with agricultural work" arose, and was subsequently proclaimed by the official organisations of Buddhism. It was with this attitude of submission to "socialist re-education" (shehuizhuyi gaizao) that Buddhism underwent agrarian reform (tudi gaige) in the early 1950s. So the monks were expropriated and only a proportion of their land, according to criteria set at the regional level, was restored to the monasteries. Those in rural areas were considered by the state as production units and, as such, they were subjected to successive movements of agricultural collectivisation (nongye hezuohua), and then integrated into the people's communes (renmin gongshe). Chinese Buddhism did not escape its tragic fate, despite its efforts to adapt during the first phase of the establishment of the communist government. Its situation began to deteriorate at the end of the $1950 \mathrm{~s}^{10}$; and it was almost entirely wiped out during the Cultural Revolution, when most of the monasteries were destroyed or confiscated by the state. The majority of the monks and nuns were then forced to return to secular life.

7 In the early 1980s, as Buddhism was reviving, the expression "combining Chan with agricultural work" was taken up again, this time as a slogan. It was then officially recognised as one of the "three excellent traditions of Chinese Buddhism" 11 . On the occasion of the reunion organised for the thirtieth anniversary of the Buddhist Association of China in 1983, Zhao Puchu (1907-2000), the Association's President, reinterpreted the slogan in these terms: “To adapt Buddhism to Chinese society, the 
Venerable Masters of Buddhism in our ancient history have, after several centuries of research and experimentation, established the rule "combine Chan with agricultural work'. Here we may understand the term "agricultural work" in the wider sense as the whole range of work activities in the production of goods and services useful to society. Chan means religious study and practice. [. . .] Since its foundation thirty years ago, the Buddhist Association of China has made unceasing efforts to promote this excellent tradition and, in the spirit of the maxim 'A day without work is a day without food' (yiri buzuo, yiri bushi) ${ }^{12}$, it has always encouraged all Buddhists to take an active share in productive labour or in any other activity that may serve the building of socialism. Today, as we find ourselves in the new situation of socialist modernisation, we Buddhists must further develop this excellent tradition of Chinese Buddhism." ${ }_{13}$

8 This speech became, in the years that followed, the guiding principle of the monastic organisation. The monasteries, those that were restored to Buddhist hands and newly rebuilt, organised the monks' work so that they took an active part in agricultural tasks, by working on the land returned to them by the state. Decollectivisation has sometimes brought about the same situation that preceded the Cultural Revolution. The land was entrusted to the monks to resume their work on it or to the local authorities who rented it out to the monasteries (in the context of the system of the chengbao).

9 Fujian is the province where the greatest number of Buddhist monasteries is to be found. It is particularly appropriate for us to observe there to what extent the principle "combine Chan with agricultural work" was applied. An investigation into the economic situation of 16 monasteries in the Ningde region ${ }^{14}$ indicates that, in 1983, 246 monks and lay Buddhists lived in these monasteries and that their annual income totalled 163,935 yuan. Of that sum $14 \%$ came from the sale of food and from the income raised by offering accommodation to visitors, and $10.3 \%$ from donations by the faithful and from payment for religious services; the harvest from the fields and from forestry provided $75.7 \%$ of their income. According to the "Report on the Third Meeting of the Buddhist Monasteries of Fujian Devoted to the Exchange of Production Experience", published by the Buddhist Association of that province $^{15}$, in 1983, 1,176 monks were living in the 50 monasteries whose delegates had attended the meeting. The monasteries had at that time 135.6 hectares of cultivated land producing 187,246 kilos of rice. In addition, they reforested 162.8 hectares of mountainside and planted 30,500 fruit trees. Thanks to this work, in 1983 their income totalled 528,036 yuan and the annual income per head rose to 450 yuan. According to the "Report on the Fourth Meeting Devoted to the Exchange of Production Experience", published the following year, the annual income per head in 80 monasteries had risen by 1984 to 1,004 yuan $^{16}$, which was a relatively large sum for that time.

Not all monasteries had fields. Some built factories or clinics; others traded in Buddhist good-luck charms and charged an entry fee for visitors to the monasteries. Others again opened hotels or vegetarian restaurants, and so on. These "combinations of Chan with industrial work" and "combinations of Chan with commerce" have sometimes been interpreted as new variations of "combinations of Chan with agricultural work"17.

11 To encourage the monasteries to go in for "productive labour", some articles seeking to show that "labour" is an essential condition of Chinese Buddhism were published in the official journal of the Buddhist Association of China, Fayin. In 1985, 1986 and 1988, this 
journal even carried a regular feature entitled "Models of Chan combined with agricultural work" (nong chan fengfan) reporting on exemplary monasteries.

It is easy to understand why Chinese Buddhism should have chosen at that time to intensify the combination of Chan with agricultural work. In the early 1980s, the relationship between the state and Buddhism was extremely unbalanced. The state refused to take responsibility for having destroyed Buddhism, and the financial situation of the monasteries was very precarious. For many monks, agriculture was just about the only means of survival.

What is more, and this point is certainly the most significant, Buddhism and the other religions had for a long time been stigmatised by the state. To some extent, Buddhism was still considered as a pernicious leftover from the old society, a superstition destined to disappear. Faced with this condemnation, Buddhism was obliged, as in the 1950s, to seek some way of legitimising its existence in a "socialist" society. Thus, on the economic front, the monks had to take a direct share of physical work, to avoid being accused of exploiting the masses, of being parasites. Putting it another way, the purpose of introducing "the combination of Chan and agricultural work" was not only to ensure the survival of the monastic community but also to harmonise monastic life with the labour ethic imposed by the state. Monks had to be seen as "hardworking" and Buddhism as "useful". Consequently, it was hardly surprising to hear in nearly all broadcast reports devoted to the success of the "combination of Chan and agricultural work" this repeated sentence: "The monks are contributing to building the socialist state."

"Cultivate the good earth" and "make merit": towards a monastic economy founded on cultural capital

In the 1990s, after an initial phase of rebirth and progress, the Buddhist monasteries progressively turned away from "productive labour". In the official discourse, the slogan "combining Chan with agricultural work" appeared less favoured. Indeed, the ethos changed. The sacred aura surrounding physical work melted away and agriculture ceased to be the first preoccupation of the Chinese state. Consequently, Buddhism had no further strategic need to cling to agricultural work to justify its existence.

Little by little, Buddhism was rehabilitated ${ }^{18}$. The number of Buddhists swiftly increased and the economic reforms allowed rapid growth in their purchasing power. An increasingly significant role was played in the monastic economy by financial support from believers. According to my field observations, from the early $1990 \mathrm{~s}$ onwards, gifts from lay people and payments in exchange for religious services organised for lay people became the main source of income for most monasteries ${ }^{19}$.

It is difficult to find precise figures to evaluate the financial contribution from believers to the monastic economy. Nevertheless, some examples are revealing. Temple B, where I began a field study in 1994, is in the province of Hebei. It has no arable land, and has no commercial activity other than the sale of books and Buddhist artefacts. Yet, this temple underwent rapid development. Rebuilding work started in 1988. A lay Buddhist in the locality had offered the monks a contribution of 100,000 yuan for the main hall and, thanks to a Chinese Buddhist living in the United States, a new wing could also be built at the temple entrance. From 1993 onwards, significant financial support began flowing in from the Hong Kong business community and from believers across the 
country. Since the late 1990s, the temple's annual budget has risen to around ten million yuan. The whole of this sum comes from financial donations by believers.

Temple Z in Jiangxi was given back to the Buddhists in 1982. In the 1980s, all its monks took part in agricultural work and the temple was cited several times in Fayin as a model for having successfully combined Chan with productive work. Today it is the lay farm labourers employed by the temple who take care of the paddy fields. The monks take no part in field work except at peak periods of agricultural activity: they devote themselves almost exclusively to Chan meditation. They say that the financial support from believers is enough to support them and that agricultural work has become a symbolic practice.

Why do Buddhists give significant sums of money to the monasteries? In fact, these gifts are part of a transaction. If a temple is in a position to obtain support from lay Buddhists, it is because it possesses cultural capital that, in some circumstances, can supply the object of exchange ${ }^{20}$.

19 This exchange often takes place in a way that is symbolically institutionalised. In spite of a two-thousand-year-long process of assimilation to China, Chinese Buddhism is still, in essence, a religion of other-worldly orientation with a dualist classification of religious virtue. Monks who devote themselves to recapturing the extreme state of illumination revealed by the Buddha are the models and the masters of the lay believers. The latter can obtain only "a relative optimum of salvation by showing their devotion to the holy examples" ${ }^{21}$. The monastery and its monks are a sacred cause. By representing the Buddha and Dharma, the monks have the authority and the capacity, made legitimate by tradition and by the Master's charisma, to interpret doctrine, to organise rites and to follow other-worldly practices. For this reason, it is in principle compulsory for lay Buddhists to make offerings to the monks from which they also will benefit, as in all religions. In Chinese, this exchange is called "cultivating the good earth" (zhong futian) ${ }^{22}$ or "making merit" (zuo gongde). Lay people may have their reward, either a purely moral one or carrying with it the hope of possible material benefits. 
Renovation work at ount Wutai, Shanxi

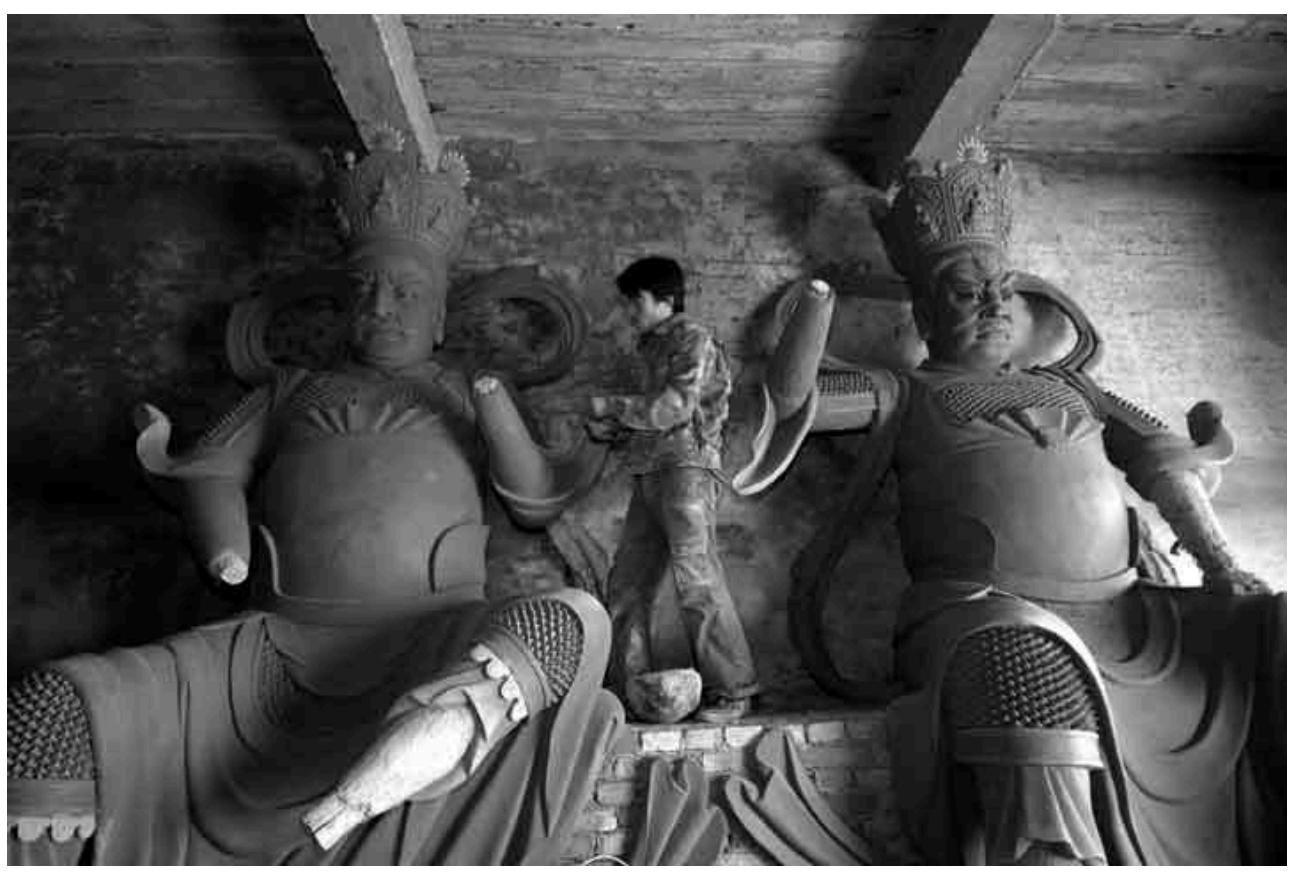

(C) Imaginechina

20 A whole range of practices are followed in the monasteries. We shall cite here two examples. The "ceremony of water and earth" (shuilu fahui) is one of the greatest Buddhist rites and is performed for the salvation of the deceased. The presiding Master gives an address extolling the merits of the original donor of the service. In some circumstances, a poem may be composed in his honour. A ceremony like this may cost several hundred thousand yuan, most of it paid in the form of cash donations to the monks who organise it and take part in it. Because of the shortage of religious premises, most of the donations from believers are at present used for building or rebuilding monasteries. In many of these one finds plaques on which are inscribed the names of the donors and what they contributed. In this kind of exchange of material wealth for symbolic wealth, the conversion rate is sometimes specified. In Temple B, mentioned above, the building of an imposing new wing required about forty million yuan. All those who gave money for the building were registered. The names of those whose contributions amounted to several hundred yuan or more were engraved on a plaque, while the names of those who gave more than 1,000 yuan were engraved on the back of a statue of the Buddha.

21 The increasing contribution that lay believers' donations make to the monastic economy has had a considerable influence on contemporary Buddhism. Buddhists flock to the temples in order to satisfy their need for symbolic solace. It helps to give meaning to their experience of life, to lessen their suffering or to make their dreams come true. Thus, if a monastery wishes to attract believers, it has to consolidate its cultural authority and strengthen its capacity to manage its symbolic capital. In the eyes of the lay community, the monastery must appear profoundly religious and sacred. Temporal business does nothing for sacredness; and today, if a temple devotes itself too much to non-religious activity, it risks the disapproval of lay Buddhists and the loss of a more profitable source of income than any other. The monasteries enjoying a good reputation for the purity of their "style in religious practice" (daofeng), 
those that had a significant place in history and are now recognised as ancestral courts (zuting) ${ }^{23}$, or those now led by "superior monks and great virtuous" (gaoseng dade) succeed more easily in attracting donations from lay believers.

The monks are fully aware of the nature of their capital, and this is one reason why the monasteries take great care to display their historical heritage. These days it is essential for them to piece together their own histories, to celebrate the anniversaries of their foundation or those of their great Masters of past years. Here we may cite two examples. In 2002, the Hanshan Temple, in Jiangsu, celebrating its 1,500th anniversary, published several volumes dedicated to its own history and to that of the great Masters who had once lived there. In 2003, the monks of the Nanhua Temple in Guangdong, also celebrating the anniversary of the founding of their temple, organised a series of activities including, in particular, a concert of Buddhist music. In this way, these monasteries and their monks lay claim to a religious prestige that they negotiate in a sort of symbolic marketplace.

23 A further significant example is the Shaolin Temple's unremitting struggle to protect its Shaolin brand, or shaolinsi. Being famed across the world for its martial arts tradition, this temple had to confront a hundred or so fake versions of its brand in 11 countries. In 1994, it decided to react. It brought a successful lawsuit against a food factory using Shaolin as its own brand name. In subsequent years, it emerged victorious in other lawsuits in China and abroad. Today the Shaolin Temple owns the registered trademark for 48 types of products and services in China. Its applications to register the trademark have been made in 68 foreign countries. Shaolin is not an isolated case. Since 2003, the Hanshan Temple has registered its own trading name as well as those of the great Masters from its history, and even one line dating from the Tang Dynasty describing the Temple.

"Culture builds the stage and the economy performs": a new relationship between the state and Buddhism

A monastic economy based on exchanges between cultural capital and material capital has taken the place of a self-sufficient economy based on agricultural work, craftsmanship and small traders. This evolution has remodelled the state's relationship with Buddhism.

25 As Buddhism's influence among lay people increases and exchanges between monasteries and believers become more frequent, the relationship between the state and the monasteries has changed into a three-cornered affair. In addition to the monks, the state must now face up to the lay believers whose interest in Buddhism is more and more intense. The Chinese government, and in particular the local authorities who are anxious to favour economic development, can no longer neglect the existence and the needs of lay Buddhists who are at the same time investors and consumers.

Attracting investors is now a key objective of the local authorities. At the present time, Hong Kong and Taiwan are an important source of capital ${ }^{24}$, and numerous investors are Buddhist. The latter are attentive not only to the communications network and to natural and human resources but also to the religious environment. Moreover, their decisions in the economic field are often influenced by Buddhist masters whom they trust. Thus, the government sees itself forced into seeking co-operation with the monasteries. According to a report published by the Buddhist Association of China, the Guangjiao Temple, in Jiangsu, has several times joined forces with the local authorities to persuade business folk in Hong Kong, Taiwan and Japan to open up enterprises in 
Nantong ${ }^{25}$. Mr Yang, a Hong Kong retailer, has since 1993 given several million yuan to Temple B in Hebei, where I carried out part of my field study. The local authority quickly understood that, Yang being Buddhist, his attachment to the regional temple might ensure that he would follow up his investments. So a top provincial official brought Temple B to his attention, a strategy that turned out effective.

It is common for religious ceremonies to attract many believers; this is an important factor in the development of tourism and of the whole of the tertiary sector of a region's industry. The production of, and trade in, religious artefacts (statues of the Buddha, strings of beads, good-luck charms, incense, candles, printed icons, and so on) are a considerable source of income for the local people. Accordingly, the local authorities often look positively on the building of monasteries and Buddhist monuments. Each year, Temple B opens its doors to a large number of visitors, as many as ten thousand a day at the time of the biggest ceremonies. In a district with few attractions, such crowds are extraordinary. The local authority was encouraged to lend support to almost all the projects undertaken by the temple and especially to its purchase of land for large-scale construction projects. On its own initiative, in 2002, a market for religious objects was installed in front of the temple, in a space measuring 24,000 square metres.

In Shanghai, in parallel with the municipal government's work on rebuilding and enlarging the Jing'an Temple, it has laid out a commercial district alongside the Temple in a pedestrianised street. In Changsha, in Hunan, the Communist Party committee and the local council are at present directing the renovation of the Kaifu Temple, which is to occupy an area of five to twelve hectares after work aimed at "improving the quality of the different services of the city and its environment, raising its cultural level and promoting the development of local trade and religious tourism". In the city of Nanking, in Jiangsu, the departments responsible for construction and gardens in the Xuanwu district have spent five million yuan on building a museum dedicated to Xuanzang (602?-664), a Chinese monk of the Tang Dynasty who went to India and brought back numerous Sutras. In the same city, two local administrations had plans to rebuild the Pagoda of the Dabaoen Temple that was destroyed in 1865 during the Taiping Rebellion. The city government finally decided to rebuild it on its former site ${ }^{26}$. Not only does the state work towards rebuilding Buddhist sites, but it also seeks to exploit the tourist potential of existing monasteries. In Jiangsu, the Tourism Bureau organises celebrations around great temples such as the Hanshan Temple and the Daming Temple on January 1st and over the Chinese New Year. On nearly all the Buddhist Mountain Sanctuaries, such as Mount Emei in Sichuan and Mount Heng in Hunan, Buddhism is at the heart of strategies for developing tourism. In Shaanxi, every year since 2001, the authorities in the city of Baoji have been organising a tourism festival at the Famen Temple. In 2003, the Zhejiang government did not hesitate to invent a festival called the Festival of the Bodhisattva of the South Sea on Mount Putuo, in order "to stimulate the development of the tourist economy" ${ }^{27}$. In 2004, the Xinzhou city government in Shanxi decided to sponsor a "Festival of Buddhist Culture" on Mount Wutai, with the participation of monasteries in the region.

In general, the monasteries choose to co-ordinate their activities with the tasks assigned by the local authorities. Although they are often under obligation to do so and although the various local government departments take the lion's share of the profit, the monasteries do benefit from the organisation of these activities. The monks are 
enabled in effect to put Buddhism in contact with the public, in a society where religion is often officially excluded from public life, to build monasteries and to organise religious activities quite lawfully. "The development of tourism" just like "the development of a favourable environment for investment" helps Buddhism and the state to reach a compromise: wearing politically correct clothing, each side can reap the benefits it seeks.

31 Mount Heng, where there are many Buddhist monasteries, is an excellent illustration of these links between the state and the monasteries. The local government has granted to an eminent monk in the region the honorary title of "Head Tourism Guide" and, conversely, a monastery organises on its own initiative, occasionally, days of activities aimed at promoting Buddhism among lay people in the context of "cultural and religious tourism". In June 2003, the leading monk in the Jiming Temple in Nanking signed a contract with the local authority for "the tourist exploitation of the Mount Donglu region"; the main project is the building of a temple. Today, the state and the monasteries are committed to a relationship of co-operation that is working out profitably for both sides.

32 Admittedly, co-operation is only one aspect of the relations between the state and the monasteries. The state appropriates a large part of Buddhism's resources: this is done mainly through departments responsible for tourism. The government continues to seize many monasteries, especially those that have a significant religious and cultural heritage. Some monasteries already restored to the Buddhists are forced into submitting to "co-management" with the local tourism bureau. The government's intention in some cases is to manage the material or symbolic property of Buddhism exactly as it pleases. While recent changes should not mask the continuance of such behaviour, it is possible to assert that the one-sided relationship that formerly existed between the state and the monasteries has developed into a more complex relationship.

The changes that have taken place within this relationship over the past two decades may be perceived as a process of revision to a game in which each player chooses a strategy according to his capital, his objectives and his estimate of the capital and objectives of the other players. The rules of the game depend on the number of players, and on the form and value of their capital; on how deep are the changes made and in which direction. In the days of the slogan "combining Chan with agricultural work", the state possessed all the resources and was thus in a position of absolute mastery. The monasteries were then forced to observe the rules as defined by the state, the Buddhist term "excellent tradition" being no more than a translation of these rules.

A decade after the policy of reform and openness was introduced, the believers began to take a hand in the game. Since they had the economic capital, they contributed to promoting the cultural capital of Buddhism, thus having a profound effect on the interaction between monasteries and state. The latter used its political power as capital, authorising it to decide which practices and discourse were possible. As for Buddhism, its capital was founded on the symbolic power of religion, which enabled it to mobilise believers or amateurs of Buddhist culture. The state's political capital cannot be directly exchanged for the economic capital of the Buddhist believers because it must first be converted into religious cultural capital. So the state, and in particular local government, is obliged to seek an alternative method of transaction with the monasteries. While the state can seize some Buddhist resources using its 
political power, it is nevertheless indispensable for it to co-operate with the monks, because the exploitation of the Buddhist cultural capital demands that Buddhist authority should grant it symbolic recognition.

The important thing for the government has always been, not the development of Buddhism itself, but the economic benefit that can be extracted from it. This may be illustrated by a slogan often quoted in the official discourse: "Culture builds the stage and the economy performs" (wenhua datai, jingji changxi). But the measures the government has taken in favour of economic development over these past ten years have nevertheless granted for Buddhism a space in which it can develop quite legitimately. So Buddhism and the state are today involved in a complex relationship: a game in which each, in its own interests, must take account of the other, and the interests of one sometimes require it first to work for the interests of the other.

\section{NOTES}

1. In 1953, the Buddhist Association of China was founded, a national organisation to head all the monasteries on Chinese soil. Up to now, it has been through its supervision of the Association that the Chinese state has regulated the practice of Buddhism. For example, the Association's nomination of the head of a monastery has to be submitted for the approval of the Religious Affairs Bureau. Yet while the Chinese government's policy towards religious institutions is constantly evolving, the policy is applied with much variation according to the interests of local authorities and the precise form of their relationships with the monasteries. See the case study by Wu Fei, "Yige simiao de zhidu bianqian" (The Institutional Change of a Temple), Beijing daxue yanjiusheng xuekan (Peking University Graduate Student Journal), No. 1, 1998, pp. 28-38. In this study Wu Fei shows clearly the complex and changing relations between a Buddhist temple, the local authority and local society.

2. For example, because of the influence of Buddhism with some non-Han Chinese and in some Asian countries, Buddhist interventions among ethnic minorities or in diplomatic relations confer a form of legitimacy on Buddhism and thus raise significant issues.

3. Chan is a Chinese Buddhist order that was created in the seventh and eighth centuries. Because of its primary influence on Chinese Buddhism, the word Chan is sometimes used to designate Buddhism as a whole. See, for example, Paul Demiéville, Choix d'études bouddhiques, Leiden, E. J. Brill, 1973, and Bernard Faure, Chan Insights and Oversights: An Epistemological Critique of the Chan Tradition, Princeton, Princeton University Press, 1993.

4. Cf. Hong Jinlian, Taixu dashi de fojiao xiandaihua zhi yanjiu (Great Master Taixu's Modernization of Buddhism), Taipei, Dongchu chubanshe, 1995; Don Alvin Pittman, Toward a Modern Chinese Buddhism. Taixu's Reforms, Honolulu, University of Hawaii Press, 2001.

5. On the historical impact of Baizhang Huaihai's ideas on China's monastic economy, cf. Shengkai, "Lun Zhongguo fojiao dui shengchan taidu de zhuanbian" (The changing 
attitudes of Chinese Buddhism towards productive work, World Hongming Philosophical Quarterly, March 2003, http://www.whpq.org/whpq/200003/200003/007.htm. For an in-depth study in French on the monastic economy in imperial times, see Jacques Gernet, Les Aspects économiques du bouddhisme dans la société chinoise du $V^{e}$ au $X^{e}$ siècle, Ecole française d'Extrême-Orient (EFEO), vol. 39, Paris, 1956.

6. Cf. Taixu, "Seng zhi jin lun" (Essay on a monastic institution), in Taixu dashi quanshu (Complete Works of the Great Master Taixu), Taipei, Shandaosi, 1980, 3rd edition, vol. 17, pp. 195-199; "Rengong yu fo hua zhi xin seng hua" (The new community of monks combining work with religious studies), ibid, vol. 18, pp. 163-166. At the time, the proposal for professional differentiation in religious communities had the primary aim of distinguishing monks with a real religious vocation from those for whom Buddhism was simply a way of life. It was hoped also to protect Buddhist property from threats by anti-religious political forces. Cf. Hong Jinlian, op. cit., pp. 62-63, p.73, and IV-1.

7. Cf. Holmes Welch, The Practice of Chinese Buddhism: 1900-1950, Cambridge, Harvard University Press, 1967, Chapter VIII.

8. Juzan, "Yinian lai gongzuo de zibai" (Record of work carried out during the past year), Xiandai foxue (Modern Buddhist Studies), vol. 1, No. 2, 1950, p. 22.

9. Cf. the early editions of Xiandai foxue at the start of the 1950s. This journal, then edited by Juzan, became the official journal of the Buddhist Association of China founded in 1953. It ceased publication in 1964.

10. The situation becomes particularly critical in 1957, at the start of the anti-rightist movement (fanyou). For a study of the general situation in which Chinese Buddhism found itself during the 1950s and 1960s, cf. Holmes Welch, Buddhism under Mao, Cambridge, Mass., Harvard University Press, 1972.

11. The other two "excellent traditions" are "intellectual study" (xueshu yuanjiu) and "international friendly exchange" (guoji youhao jiaoliu). Cf. Zhao Puchu, "Zhongguo fojiao xiehui sanshi nian" (Thirty years of the Buddhist Association of China), Fayin (Voice of Dharma), No. 6, 1983, pp. 13-21; "Fayang fojiao youliang chuantong, wei zuguo shehuizhuyi shiye er xianshen" (Developing excellent traditions to devote oneself to the socialist undertaking of one's country), Fayin, No. 1, 1982, pp. 2-4. Since 1981, Fayin has been the official journal of the Buddhist Association of China.

12. This maxim comes from an anecdote on the Chan master Baizhang Huaihai. Baizhang was forever working with his disciples. One day, a monk hid his work tools so that he might rest. Baizhang said, "I have no virtue: how can I depend on other people's work?" He looked everywhere for his tools, so much so that he forgot to eat. Cf. Puji (South Song), "Baizhang Huaihai chanshi" (Master Chan Baizhang Huaihai), Wu deng hui yuan, Peking, Zhonghua shuju, 1984, III, p. 136. This maxim is often quoted today to show that agricultural work is part of the tradition of Chinese Buddhism.

13. Zhao Puchu, ibid.

14. Renren, "Nong chan bingzhong, zili lita. Fujian Ningde diqu shiliu zhuo simiao xingban shengchan fuwu shiye de qingkuang diaocha" (Combining Chan with agricultural work, doing good for oneself and for others. Investigation on the economic situation of 16 monasteries in the Ningde region of Fujian), Fayin No. 3, 1985, pp. 24-26. 15. Un-attributed article: "Fayang nong chan bingzhong de chuantong. Foxie Fujian fenhui zhaokai di san ci simiao shengchan jingyan jiaoliuhui" (Developing the excellent tradition of combining Chan with agricultural work. Report on the third meeting of the Buddhist monasteries of Fujian devoted to exchanging experiences in the matter of production), Fayin, No. 3, 1984, pp. 9-10. 
16. Minfo, "Fujian sheng fojiao simiao di si ci shengchan jingyan jiaoliu dahui zai rong zhaokai" (Report on the fourth meeting of the Buddhist monasteries of Fujian devoted to exchanging experiences in the matter of production), Fayin, No. 3, 1985, p. 26.

17. Cf. Chen Bing, "Fojiao yu shehuizhuyi xiang xietiao wenti" (On adapting Buddhism to Socialism), Fayin, No. 12, 1991, pp. 14-18.

18. By the mid 1990s, regions inhabited by ethnic Han already included 40,000 monks and nuns, 5,000 monasteries and about twenty Buddhist schools, cf. Jinghui, "Jinri Zhongguo fojiao gaikuang" (General situation of Chinese Buddhism today), Huadu fayu (The Rain of Dharma in Paris), Peking, Sanlian shudian, 1994, pp. 3-4.

19. Raoul Birnbaum has made the same point, cf. his "Buddhist China at the Century's Turn", The China Quarterly, No. 174, June 2003, pp. 442-443. It is often difficult to make a distinction between donations from lay people and the income from religious services, except in some specific cases, such as, for example, funeral rites. Even though this expectation is not always expressed, the donation often demands a service or a promise in exchange. Conversely, lay people may also pay for religious services in the form of deferred gifts. In my view, these two types of transactions can be summed up as an exchange between material capital and cultural capital.

20. On the concept of cultural capital and its symbolisation, cf. Pierre Bourdieu, "The Forms of Capital", in J Richardson (ed), Handbook of Theory and Research for the Sociology of Education, New York, Greenwood Press, 1988, pp. 241-258; Raisons pratiques, Paris, Seuil, 1994, p. 161.

21. Max Weber, Sociologie des religions, Paris, Gallimard, 1996, p. 169 ; see also ibid, p. 334. 22. Cf. Wu Yongmeng, "Fojia de futian guan jiqi fuli sixiang" (The notion of futian and the idea of well-being in Buddhism), Wenyi fuxing, No. 60, 1975, Taipei, pp. 43-50.

23. A Buddhist monastery where in ancient history there once lived a great Master, often the place of origin of a lineage.

24. Since the start of the economic reforms, each year, investment from Hong Kong has added up to over $30 \%$ of total foreign investment, direct or indirect, in mainland China and has been greater than the investment from any other single country or region. Taiwan is also among the most important investors in mainland China. See the statistical yearbooks for these past years (Zhongguo tongji nianjian) compiled by the National Statistical Bureau, and published by Zhongguo tongji chubanshe.

25. Yuelang, "Shilun simiao zai gaige kaifang xinxinshi xia de diwei he zuoyong" (The position and the function of the monasteries in the context of the reforms and openness), Dangdai fojiao (Contemporary Buddhism), edited by Jinghui and Kuanren, Peking, Buddhist Association of China, 1996, pp. 202-205.

26. Jinling Wanbao (Nanking Evening News), August 9th 2002.

27. http://guanyin.zjol.com.cn. In reality, two festivals are superimposed. First of all there is the traditional, religious, festival of Nanhai Guanyin, which is held in a Buddhist holy place. And in parallel is held the modern festival, organised by the state in response to the aims of local economic development. 


\section{RÉSUMÉS}

In the early 1980s, Buddhism in China entered a period of revival and prosperity, yet it retained a sense of public disgrace inherited from nearly three decades of persecution. In order to survive and to conform to the ethical system imposed by the government, the monks were forced to engage in "productive labour". However, Buddhism's growing influence among lay people, and the increasing number of exchanges between monasteries and believers promoted a steady growth in the value of Buddhism's cultural and religious capital. From the 1990s onwards, local authorities sought to co-operate with Buddhism, hoping to profit by its cultural capital through attracting investors and promoting tourism. The state did not cease to control and to oppress the Buddhists although, guided by economic interests, it contributed in some cases to promoting and reconstructing Buddhism: the monasteries thus found new legitimacy and new space for development. 